\title{
From a property tax to a land tax - who wins, who loses?
}

Article

Accepted Version

Creative Commons: Attribution-Noncommercial-No Derivative Works 4.0

Wyatt, P. (2019) From a property tax to a land tax - who wins, who loses? Land Use Policy, 88. 104172. ISSN 0264-8377 doi: https://doi.org/10.1016/j.landusepol.2019.104172 Available at https://centaur.reading.ac.uk/85594/

It is advisable to refer to the publisher's version if you intend to cite from the work. See Guidance on citing.

To link to this article DOI: http://dx.doi.org/10.1016/j.landusepol.2019.104172

Publisher: Elsevier

All outputs in CentAUR are protected by Intellectual Property Rights law, including copyright law. Copyright and IPR is retained by the creators or other copyright holders. Terms and conditions for use of this material are defined in the End User Agreement.

\section{www.reading.ac.uk/centaur}

\section{CentAUR}

Central Archive at the University of Reading

Reading's research outputs online 
FROM A PROPERTY TAX TO A LAND TAX - WHO WINS, WHO LOSES?

\section{ABSTRACT}

Whilst the theoretical case in favour of a tax on the value of land (a land tax) is well established, examples of its implementation in practice are relatively few in number. Where a land tax is levied, it is often part of a suite of land and property taxes that includes transfer taxes, wealth taxes betterment and recurrent taxes on land and property. Rarely is a land tax the sole mechanism for taxing real estate. Yet there is no shortage of land tax supporters, even in countries where other forms of real estate tax have a long history. England is one such country, where real estate taxes have existed since the 17th century in one form or another. Despite coming close at the beginning of the 19th century, governments on the left, right and in the centre ground of political discourse have not implemented a land tax.

In the land tax debate throughout this period, there was an absence of empirical research to underpin the positions adopted by either proponents of a land tax or defenders of the status quo. It was not until 1964 that a small pilot exercise was undertaken to investigate the implications of introducing a land tax in England. This seems odd given that frequently cited criticisms of a land tax centre on its practical difficulties. This paper, therefore, looks at some of the consequences of switching from recurrent real estate taxes that are based on the value of land and improvements to one that is based on the value of land only. Focusing on one local authority area in the south east of England, the paper answers the following questions: how might the valuation of land be undertaken in a developed economy where most transactional evidence relates to land together with improvements, and what are the revenue implications of switching from a tax where the liability falls on the land owner rather than the property occupier in first instance. In particular, who are the winners and losers and does expansion of the tax base to include agricultural land uses significantly increase tax revenue?

\section{ACKNOWLEDGEMENTS}

The author gratefully acknowledges the helpful comments from the reviewers of this paper. 


\section{FROM A PROPERTY TAX TO A LAND TAX - WHO WINS, WHO LOSES?}

\section{INTRODUCTION}

Whilst the theoretical case in favour of a tax on the value of land (a land tax) is well established, examples of its implementation in practice are relatively few in number. Where a land tax is levied, it is often part of a suite of land and property taxes that includes transfer taxes, wealth taxes betterment and recurrent land taxes. Rarely is a land tax the sole mechanism for taxing real estate.

Yet there is no shortage of land tax supporters, even in countries where other forms of real estate tax have a long history. England is one such country, where real estate taxes have existed since the $17^{\text {th }}$ century in one form or another. Taking the form of local rates, land and property taxation first appeared in the UK in the $16^{\text {th }}$ century following the Reformation, but it was not until 1909 that, under the influence of Henry George, the Liberal Government introduced a recurrent land value tax. However, the tax did not survive long enough to be implemented and was eventually abolished following a change of Government in 1922. In the decades that followed, despite sound theoretical arguments in support of land value taxation, coupled with strong lobbying, a land value tax has not been implemented in England.

It is interesting to note that, in the land tax debate throughout this period, there was an absence of empirical research to underpin the positions adopted by either proponents of a land tax or defenders of the status quo. The debate was a political, ideological and theoretical one (McGill and Plimmer, 2004). It was not until 1964 that a small pilot exercise was undertaken to investigate the implications of introducing a land tax in England. This seems odd given that frequently cited criticisms of a land tax centre on technical difficulties, and particularly the need to value land separate from any improvements even though most transactional evidence relates to land and improvements combined. It would be useful to investigate these difficulties to see if circumstances have changed. This paper, therefore, models the possible consequences of switching from recurrent real estate taxes that are based on land and improvements (or land and property) to one that is based on the value of land only, and from shifting the initial liability for payment of the tax from property occupiers to land owners. Focusing on one local authority area in the south east of England, the paper seeks to answer the following two questions: 
- How might the valuation of land be undertaken England where most transactional evidence relates to land and property?

- What are the revenue implications of switching from a tax where the liability falls on the land owner rather than the property occupier in first instance? In particular, who are the winners and losers and does inclusion of agricultural land uses in the tax base significantly increase tax revenue?

\section{THE THEORETICAL CASE FOR A LAND TAX}

The theoretical case for a recurrent tax based on the value of land is well documented. Classical and neo-classical economists such as Adam Smith, David Ricardo, John Stuart Mill and Alfred Marshall demonstrated that the economic rent (and its capitalised equivalent, value) which land is able to earn over and above the return generated after optimally employing labour and capital is determined by its scarcity and its location, neither of which are derived from any productive activity on the part of the landowner. Land value is, therefore, the price of monopoly: the scarcer and less substitutable a parcel of land is, and the more attractive the location in relation to the market and factors of production, the more valuable the land.

Land use planning and regulation, which are not the result of landowner action, create further scarcity, increasing the value of land in specific locations. At the land parcel level, the grant of permission to develop land (including changing its use) can generate substantial increases in land value. In societies where governments provide infrastructure, services and amenities, landowners may also benefit from value uplift as a direct result of this publicly funded investment and it is argued that the public has a legitimate claim to this land value.

Who receives economic rent depends on who owns the land and the mechanisms in place to collect it. Debate over entitlement to these legal rights over land (including the right to use, exclude others, reap economic benefit, transfer, inherit, etc.) has a recorded history of at least four centuries: whether such rights should be privately owned and state protected (Locke, Bentham) or publicly owned (Rousseau, Marx). As global population and the rate of urbanisation increase, pressure on land resources grows, and the philosophical debate over land rights intensifies, with socioeconomic concerns over access to and distribution of land and its associated wealth (de Soto, 2000). 
In countries where property rights are held privately, the combination of private property rights and monopoly land value creates two social costs: unearned land value (or wealth) and unequal distribution of that wealth. One means of recovering unearned land value is a tax. Adam Smith argued that a tax on land value would not harm economic activity and would not increase land rents. The idea of a recurrent tax on land value has been propounded ever since with 19th century liberal economist Henry George making the most well-known case for a single tax on land value (George, 2005). However, a single tax on land that replaces all other taxes has not been introduced, the most likely reason being that a wealth tax on such a scale could dramatically reduce land values. Instead, the idea of a land tax as a single land and property tax has been advocated, but these are usually at low rates and capture only a small fraction of value.

Other reasons why land tax is regarded as beneficial are that it: does not distort choices as to how much to invest in improvements (Dye and England, 2010); it can encourage optimum use of land (Commission on Local Tax Reform, 2015 Vol 3, p.26-7) and reuse of vacant land (Lyons Inquiry into Local Government, 2005, p.76); by raising the holding cost of land, it may discourage land banking and speculation and encourage development; and it may encourage denser development (subject to planning) and therefore limit urban sprawl

Although the theoretical case for taxing land is well established, there are legitimate reasons for taxing improvements too. Occupiers of improved land consume local services and benefit from local amenities and this service provision needs funding, leading to a case for taxing the value of improvements. Mirrlees et al (2011) suggest that land and improvements should be thought of as distinct bases for taxation, given that the investment in improvements does not always correlate with the use of services. In reality, many countries' taxes are levied on their combined value and therefore have what could be considered as a dual role: tax on services used (waste collection, road repairs, etc.) and value of land in the basis of its existing (i.e. unimproved) use. They also argue that only residential improvements should be taxed since business premises are an input into the production process so taxing them would distort choices firms make about production (Mirrlees et al, 2011:376).

Lichfield et al stressed the need to ensure land taxation is compatible with development planning and Connellan (2004) explores the moral and ethical rationale for land taxation, as well its practical operation in the UK. Dunne (2005) and Dye and England (2011) also consider the practical issues associated with land taxation. Lyons (2011), Lyons and Wightman (2013) and Wightman (2013a and 
2013b) investigate the potential for implementing a land tax in the British Isles and in Ireland. More recently, Corlett et al (2018) suggest replacing Business Rates and Stamp Duty Land Tax on commercial transactions with a commercial landowner levy, in other words a land value tax on owners.

\section{LAND AND PROPERTY TAXATION}

Despite the theoretical case for a tax on the unearned wealth arising from land ownership, an allencompassing land tax is a rarity. Instead, a land tax usually sits alongside a gamut of direct land and property taxes which can be classified in different ways. Figure 1 categorises them as recurrent (usually annual) taxes and event-based taxes. These taxes will directly affect land value as the cost of the tax can be capitalised and deducted from the price paid for land. In addition to these are indirect taxes on land and property: VAT, which may be charged on the sale or lease of commercial property; and income tax and corporation tax, which are charged on rental income and profits from property investment. These are less likely to be directly reflected as capitalised deductions from land value as their incidence and magnitude are dependent on taxpayer decisions and status.

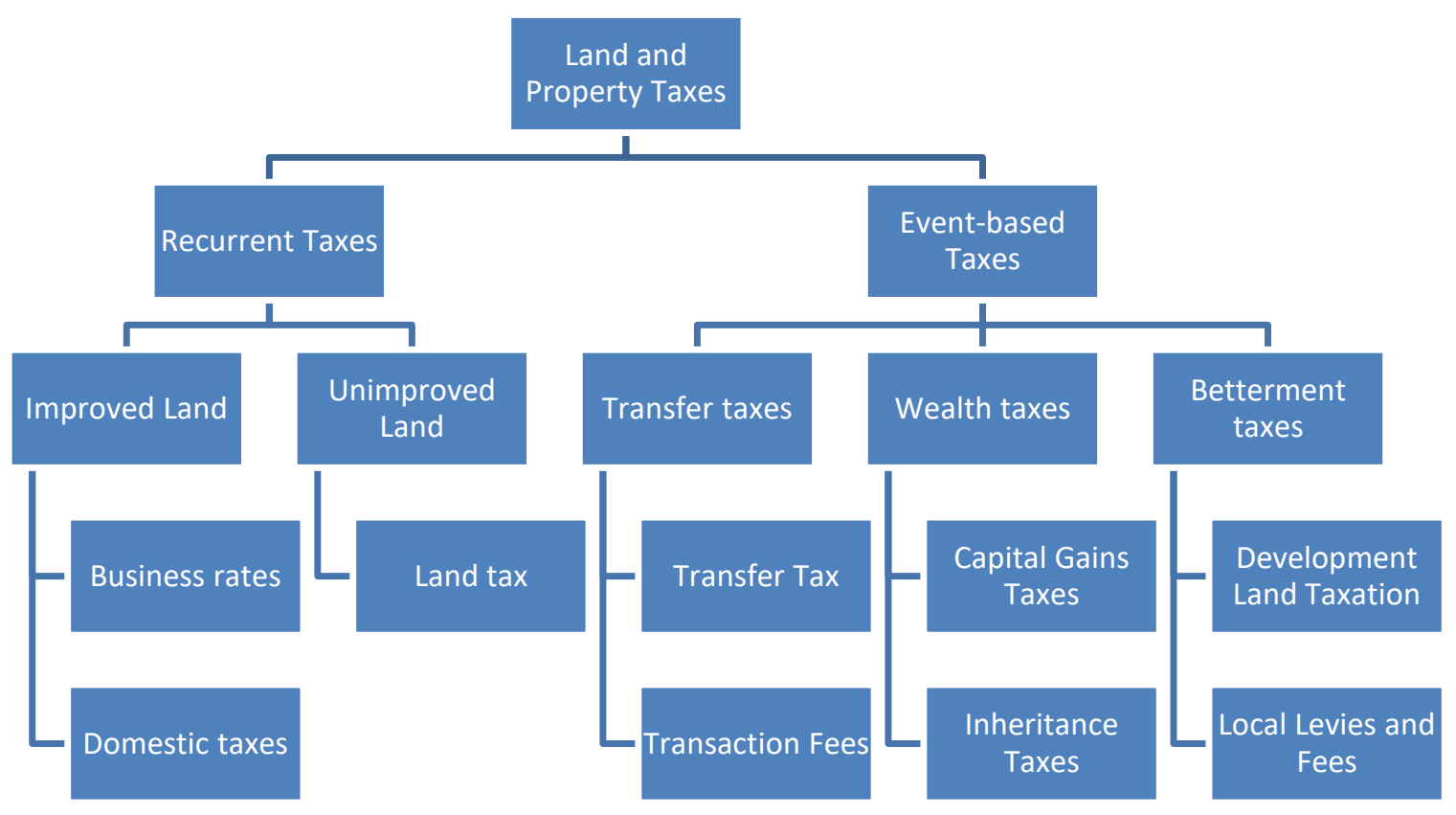

Figure 1 - Direct land and property taxes

Recurrent land and property taxes are usually assessed with reference to value of land (a land tax) or land together with improvements (a property tax) and levied as a percentage of either the annual 
(rental) or the capital value of the land parcel. Event-based taxes include transfer taxes, wealth taxes and betterment taxes. Table 1 summarises the key attributes of each of these taxes.

Table 1 - Key attributes of land and property taxes

\begin{tabular}{|l|l|l|l|l|}
\hline \multicolumn{1}{|c|}{ Type of tax } & \multicolumn{1}{|c|}{ Description } & \multicolumn{1}{|c|}{ Occurrence } & \multicolumn{1}{|c|}{ Liability } & \multicolumn{1}{|c|}{ Incidence } \\
\hline Recurrent tax & $\begin{array}{l}\text { A tax usually levied to help pay } \\
\text { for local services }\end{array}$ & Annual & $\begin{array}{l}\text { Occupiers } \\
\text { or owners }\end{array}$ & $\begin{array}{l}\text { Occupation } \\
\text { or ownership }\end{array}$ \\
\hline Transfer tax & $\begin{array}{l}\text { \% price agreed on transfer of } \\
\text { ownership }\end{array}$ & On transfer & Owners & Transfer \\
tax & $\begin{array}{l}\text { On increase in value } \\
\text { attributable to granting of } \\
\text { development rights }\end{array}$ & $\begin{array}{l}\text { On grant of planning } \\
\text { permission or } \\
\text { commencement of } \\
\text { development }\end{array}$ & Owners & $\begin{array}{l}\text { General, } \\
\text { scheme } \\
\text { specific }\end{array}$ \\
\hline $\begin{array}{l}\text { Capital gains } \\
\text { tax }\end{array}$ & $\begin{array}{l}\text { Accruing to property asset(s) } \\
\text { whose value has appreciated } \\
\text { over time }\end{array}$ & $\begin{array}{l}\text { On realisation of } \\
\text { chargeable capital } \\
\text { gain }\end{array}$ & Owners & $\begin{array}{l}\text { Wealth, } \\
\text { Transfer }\end{array}$ \\
\hline $\begin{array}{l}\text { Inheritance } \\
\text { tax }\end{array}$ & $\begin{array}{l}\text { On the value of property owned } \\
\text { at death }\end{array}$ & On death & Owners & Wealth, \\
\hline
\end{tabular}

In England, all attempts to tax value arising specifically from the grant of consent and the exercise of development rights, of which there have been four since 1947, have been short-lived and resulted in failure both in revenue terms and in bringing forward land for development. What exists in terms of event-based land and property taxes is transfer tax, capital gains tax, inheritance tax, and local betterment taxes (in the form of 'planning obligations' and infrastructure levy). England has two forms of recurrent property tax that are both based on the combined value of land and property. These are Council Tax, which is levied on domestic properties, and Business Rates levied on nondomestic properties. The taxable entity for both of these taxes is the occupier in the first instance, although owners become liable if the property is unoccupied.

Council Tax is based on capital values of dwellings. Each local authority administers and collects the tax and decides how tax revenue is spent. There are eight council tax bands, from $\mathrm{A}$ (lowest) to $\mathrm{H}$ (highest). These bands are based on estimations of the market value of residential properties as at 1 April 1991. Local councils set the band D tax rate, with the charges for properties in other bands 
being a fixed proportion of that band $D$ charge. Business Rates are based on annual rental values and are revalued on a five-yearly basis. The valuations are undertaken by a central government agency and the tax rate is set by central government each year, but individual local councils administer and collect the tax. Business Rates raise more revenue than council tax despite a far smaller tax base. There are a range of reliefs from these taxes; the main one is agricultural land and buildings. Table 2 summarises the characteristics of Council Tax and Business Rates.

Table 2 - Attributes of Council tax and Business Rates

\begin{tabular}{|l|l|}
\hline \multicolumn{1}{|c|}{ Council Tax } & \multicolumn{1}{c|}{ Business Rates } \\
\hline Based on value bands & Based on spot values \\
\hline Based on capital values & Based on annual rental values \\
\hline Local authorities set rate & Central government sets rate \\
\hline \multicolumn{2}{|c|}{ Occupiers liable (owners if property is empty) } \\
\hline Based on 1991 values and never been revalued & $\begin{array}{l}\text { Revalued every five years (seven years in one } \\
\text { case) }\end{array}$ \\
\hline $\begin{array}{l}\text { Various reliefs and exemptions, the main one } \\
\text { being 25\% discount for single occupancy }\end{array}$ & $\begin{array}{l}\text { Various reliefs and exemptions, the main one } \\
\text { being exemption for agricultural land and } \\
\text { woodland }\end{array}$ \\
\hline
\end{tabular}

Council Tax is regressive in two ways. First, the tax rate declines when moving from lower to higher value bands. Roughly speaking the percentage increase in bills between bands is half the percentage increase in property values (Hills and Sutherland, 1991). Second, the absence of revaluations means that increases in land value are not being taxed and geographical shifts in land value are not reflected. For example, in Table 3 it can be seen that 1995 the mean house price in the North of England was 25\% below the mean for England and the south east was 19\% above. By 2018 the North was $46 \%$ below and the south east was $30 \%$ above. Although house prices vary widely with each region, there has been a significant shift in prices from the north to the south, and this is not reflected in the 1991 values on which the Council Tax bandings are based.

Table 3 - Mean house prices in England and Wales 


\begin{tabular}{|c|c|c|c|c|}
\hline & 1995 average & $\begin{array}{l}\text { \% difference } \\
\text { from } 1995 \\
\text { England and } \\
\text { Wales } \\
\text { average }\end{array}$ & 2018 average & $\begin{array}{c}\text { \% difference } \\
\text { from } 2018 \\
\text { England and } \\
\text { Wales } \\
\text { average }\end{array}$ \\
\hline East Anglia & $f 60,728$ & $-11 \%$ & $£ 276,485$ & $-8 \%$ \\
\hline East Midlands & $f 54,243$ & $-20 \%$ & $£ 218,553$ & $-28 \%$ \\
\hline Greater London & $£ 97,707$ & $44 \%$ & $£ 622,813$ & $118 \%$ \\
\hline North & $f 50,675$ & $-25 \%$ & $£ 169,594$ & $-46 \%$ \\
\hline North West & $£ 50,096$ & $-26 \%$ & $£ 194,195$ & $-37 \%$ \\
\hline South East & $£ 80,515$ & $19 \%$ & $£ 379,453$ & $30 \%$ \\
\hline South West & f66,294 & $-2 \%$ & $f 290,662$ & $-2 \%$ \\
\hline Wales & $f 51,287$ & $-24 \%$ & f183,014 & $-41 \%$ \\
\hline West Midands & $f 58,884$ & $-13 \%$ & $f 227,172$ & $-25 \%$ \\
\hline Yorks and Humber & $f 54,117$ & $-20 \%$ & $f 191,736$ & $-38 \%$ \\
\hline ENGLAND AND WALES & $£ 67,915$ & & $£ 297,273$ & \\
\hline
\end{tabular}

Source: HM Land Registry House Price Index

Leishman et al (2004) looked at alternatives to the Council Tax system and Corlett and Gardiner (2013) provide a critique of the Council Tax and suggests replacing it with a progressive property tax. Business Rates are a tax on land and property and therefore it is, at least in part, economically inefficient as it taxes a production input. There are also some discounts for empty properties and this acts as a disincentive for reuse.

\section{IMPLEMENTING A LAND TAX AS A REPLACEMENT FOR A PROPERTY TAX}

There are a number of issues that need to be considered when deciding whether to introduce a land tax as a replacement for a property tax.

The first issue is the windfall loss incurred by owners of land as the tax base shifts from occupiers to owners. The main losers when switching from an occupation tax such as business rates to a land tax would be land-extensive businesses (IPPR, 2005). A broader, more inclusive tax base means that tax rates for everyone can be lower, but the UN (2011) notes that taxation of agricultural land or forest land can be politically sensitive. This may explain to some degree why many countries with a land tax apply special reliefs to agriculture, through full or partial exemptions, or lower tax rates (Norregaard, 2013). Also, the impact on other taxes needs to be carefully considered. Further, in most countries special provisions exist for heritage assets, which are deemed to require protection. 
Second, in their review of international literature, Gibb and Christie (2015) note that there is a risk that introducing a land tax may initially lead to significant land value reductions as a result of the capitalisation of future tax liabilities into the value of land. This could have significant implications for economies that rely on the wealth stored in property values as collateral for debt. To counter such a fall in values, a transitional arrangement might be appropriate, perhaps phasing in the land tax or offering compensation to those initially affected.

Third, because a land tax is usually levied on owners, this can cause confusion over the purpose of the tax. Local taxation is often regarded as a benefit or service tax to pay for the provision of local infrastructure, services and amenities. Therefore, occupiers of land, together with improvements to the land, would be the appropriate taxable entities. However, if the tax is also in part a wealth tax designed to capture uplift in value resulting from the provision of local infrastructure, services and amenities, then the landowner would be the appropriate taxable entity. In reality, a land tax is a hybrid benefit tax and wealth tax. The confusion stems from the fact that the tax is assessed by reference to values. Is the tax based on values to capture greater taxes from those with higher value properties or is it based on values because those living in higher value properties will use infrastructure, services and amenities more? Relatedly, the level of tax liability may not necessarily be correlated with ability to pay, so a mechanism might be required for taxpayers to defer payment until sale.

Turning to the more technical aspects associated with a land tax, it requires a register of land ownership that records legally identifiable boundaries and permitted land use and development rights for all sites. England does not have such a legal cadastre. Moreover, England has a plan-led discretionary system for allocating land use rights, which is different from zoning systems that delineate permitted uses on an area-by-area basis, conveying development rights to landowners without the need for detailed approval. In a zoning system the assessment of permitted use is more straightforward than a plan-led discretionary system.

It may be difficult to value land in isolation from improvements. This is because valuations rely heavily on the availability of evidence to support assessed values, but evidence of sales of land without any improvements such as buildings, particularly within urban areas is often difficult to find. An alternative is to use an approach known as the 'residual' method, whereby build costs and other adjustments are subtracted from the total value of the development to arrive at a 'residual' land 
value. The approach is used later in this paper, but it is worth noting here that it can produce confounding results. For example, take two dwellings side-by-side. One is three-storey and developed to highest and best use (market value $=£ 1 \mathrm{~m}$, build and other costs $=£ 0.5 \mathrm{~m}$, so land value $=£ 0.5 \mathrm{~m}$ ), the other is two-storey (market value $=£ 0.7 \mathrm{~m}$, build and other costs $=£ 0.3 \mathrm{~m}$, so land value $=f 0.4 \mathrm{~m}$ ). The land value (and therefore the tax) of the first property is higher. The relationship between property value and build cost is penalising the development of land to highest and best use, which is counterintuitive as far as a land tax is concerned.

This problem could be addressed by valuing the land on which the two-storey property is constructed at its 'highest and best use', in other words assuming that it is developed to threestoreys. However, the difficulty then shifts to the identification of highest and best use. One approach might be to make reference to planning policy for each plot of land and make a judgement as to whether the land is developed to its maximum reasonable capacity. However, this would be open to challenge. It would also be labour intensive and costly. Nevertheless, it is an approach used in some countries, but normally where land use is 'zoned' for planning purposes. Each land use zone is delineated and the highest and best use is established for each zone, within which property of different types would be taxed based on corresponding tax rates. This approach would need to be designed so as to acknowledge that not all land within such zones would be permitted to be developed to the zoned highest and best use by the planning system e.g. land within the setting of a sensitive heritage asset, or land which is used as public open space. Therefore, with a zoned approach, some method is required to allow for adjustment at the individual parcel level.

This raises another important point. With a zoning system it is possible to base a land tax on the 'planned' use of each piece of land, the 'highest and best use'. A discretionary planning system means that this is not possible since any change of legally permitted use only occurs once an application to do so has been granted consent. What this means is that the land value on which a land tax is based may be assessed with reference to either its highest and best use (zoning system) or its current use (discretionary system). The modelling undertaken for this paper is based on the latter-current use. 
Land tax is usually assessed as a proportion of market capital value ${ }^{1}$ of land but can also be based on market rental values. Rental values relate to market conditions but normally reflect existing use rather than how the property might be used if sold on the open market. Basing the tax on capital market value means that valuations will include 'hope value'. This is the value that purchasers of land pay in excess of the value for the permitted use. It reflects - in financial terms - speculation that there might be a change of permitted use that would increase the value of the land. Thus, if a purchaser acquires land at a price that incorporates hope value, he or she will be exposing themselves to a land tax liability based upon that value. This point is explained in the quotation below.

\begin{abstract}
‘Agricultural land at a city's edge is often more valuable for its development potential than for its agricultural production. If the land is taxed at its 'market value', meaning its value as developable land, farmers may not be able to continue farming because of high taxes. While many countries simply exclude agricultural land from the tax base, many others design a system which taxes agricultural land at its agricultural value rather than full market value.' (UN 2011: 43)
\end{abstract}

Basing land tax on assessments that include hope value could be open to challenge since its existence and extent are matters of judgement. It might therefore be preferable to value land based on a highest and best use that could reasonably be assumed to be permitted under existing local planning policy, rather than including a proportion of value which is assumed to derive from the potential to gain a planning permission for a different and more valuable use in the future should planning policy change. If a 'zoned use' approach to planning is taken, this simplifies the issue, but does give rise to the need for 'parcel adjustments' for site specific characteristics. A further difficulty arises when attempting to set the extent of highest and best use. To illustrate the point, assume a local planning authority wishes to zone agricultural land for a new town. Should each parcel of land be valued as though it were, say, residential use in isolation from any surrounding town development that might increase its value further? That would seem fair since it follows the same approach as compensation for compulsory purchase of land. The difficulty arises when trying to evidence such 'no scheme' land values.

\footnotetext{
${ }^{1}$ There are other bases of assessment: soil quality for agricultural land; and replacement cost valuations for buildings, but these are usually employed when market transaction evidence is not available.
} 


\section{PREVIOUS STUDIES OF MOVING FROM A PROPERTY TAX TO A LAND TAX IN ENGLAND}

In 1964 the Rating and Valuation Association reported on a study that investigated the hypothetical impact of a land tax or 'site value rating' as it was referred to (Rating and Valuation Association, 1964). This study piloted site value rating in Whitstable, a small town of approximately 2,000 residents in the county of Kent in south east England. Annual values of sites were assessed based on full permissible development value in accordance with the 'town map'. All land was valued, including sites of churches and so on, which could later be exempted as appropriate. The valuations were quite fine-grained; site-specific aspects such as frontage and proximity to value-enhancing and value-diminishing characteristics were taken into account. Capital values were annualised at a rate of $4 \%$. The result of the study showed that the total value on the existing rating list (based on occupied taxable units) was $£ 724,100$ whereas the site value list (based on owned land units) was $£ 642,254$, of which $£ 14,504(2 \%)$ was from agricultural land.

A follow up study (Land Institute, 1973) used the same approach. Interestingly, as far as the approach adopted in this paper is concerned, the study found a 'remarkable consistency' between land values obtained by deducting improvements from total sale price (i.e. a residual approach), and the few transactions involving bare land that were available at the time. As with the 1964 study, a relatively ad hoc decision was made to use a rate of $6 \%$ to annualise capital values. The 1973 study reported an increase in rateable value from $£ 3,186,543$ under the existing rating system to $£ 4,531,093$ under a site value rating system, opposite to the decrease reported in the 1964 study. There may be several reasons for this, but a likely contender is the rapidly growing value of land over the decade.

Thirty years later McGill and Plimmer (2004) revisited the two Whitstable pilot studies and, of particular relevance to this paper, looked in some detail at the predicted winners and losers. Those who stood to gain were owners of dwellings, retail, commercial and industrial properties, schools and playing fields, hospitals and homes. Some of the decreases in assessed value were substantial. Such reductions can be countered by raising the tax rate but, unless differential rates are implemented, there would be a significant shift in relative liabilities. Increases in value related, in the main, to public uses of land. The exception was agricultural land use, but this was previously untaxed. What the study seems to show is that replacing a property tax with a land tax means that, all else equal, those who previously paid tax based on land and property now pay less since they pay 
a tax based on land value only. However, the tax burden may be redistributed so that those in the most valuable locations pay the most tax, regardless of the value of property on the land.

A great deal has changed since the Whitstable study and, given rising land values resulting from increased development pressures, particularly for residential development, it seems appropriate to look afresh at the implications of a switch from a property tax aimed at occupiers to a land tax aimed at owners.

\section{METHOD}

The method adopted for this research is a case study. Reading, a large town situated 60 kilometres west of London in the south east of England, was selected as the study location. The area is administered by Reading Borough Council and has a population of approximately 163,000 residents and an area of just over 40 square kilometres. It comprises mainly urban land uses but with some rural land uses, and a mix of large and small owners and occupiers of land and property. Table 4 summarises the Council Tax base for the borough and Table 5 summarises the Business Rates base.

Table 4: Council Tax in Reading, 2017-18

\begin{tabular}{|c|c|c|c|c|}
\hline Band & Property value & $\begin{array}{r}\text { Charge } \\
\mathbf{2 0 1 7 / 1 8}\end{array}$ & $\begin{array}{c}\text { Number (and \%) } \\
\text { of dwellings }\end{array}$ & $\begin{array}{c}\text { Revenue } \\
\text { before reliefs }\end{array}$ \\
\hline A & up to $f 40,000$ & 1148.89 & $6,450(9 \%)$ & $7,410,341$ \\
\hline B & $f 40,001$ to $f 52,000$ & 1340.36 & $14,010(20 \%)$ & $18,778,444$ \\
\hline C & $f 52,001$ to $f 68,000$ & 1531.85 & $28,670(41 \%)$ & $43,918,140$ \\
\hline D & $f 68,001$ to $f 88,000$ & 1723.33 & $10,860(15 \%)$ & $18,715,364$ \\
\hline E & $f 88,001$ to $f 120,000$ & 2106.30 & $5,430(8 \%)$ & $11,437,209$ \\
\hline F & $f 120,001-f 160,000$ & 2489.25 & $3,270(5 \%)$ & $8,139,848$ \\
\hline G & $f 160,001-f 320,000$ & 2872.22 & $1,840(3 \%)$ & $5,284,885$ \\
\hline H & $f 320,000$ and over & 3446.66 & $80(-)$ & 275,733 \\
\hline TOTAL & & & 70,600 & $113,959,964$ \\
\hline
\end{tabular}

Table 5: Business Rates in Reading, 2017-18

\footnotetext{
2 The Rating List downloaded from the Valuation Office Agency's website (voa.gov.uk) on the $15^{\text {th }}$ July 2017 included 5,462 properties with a total rateable value of $₫ 313 m$, an average of $£ 57,000$ per property. Some of
} 


\begin{tabular}{|l|c|c|}
\hline \multicolumn{1}{|c|}{ Land use } & $\begin{array}{c}\text { Number (and } \\
\% \text { of } \\
\text { properties }\end{array}$ & $\begin{array}{c}\text { Rateable value } \\
\text { (\% of total) }\end{array}$ \\
\hline Retail and Leisure & $2,158(40 \%)$ & $£ 116,850,590(37 \%)$ \\
\hline Offices & $1,614(30 \%)$ & $£ 111,142,825(35 \%)$ \\
\hline Factories and warehouses & $886(16 \%)$ & $£ 46,842,495(15 \%)$ \\
\hline Other & $790(15 \%)$ & $£ 38,515,553(12 \%)$ \\
\hline TOTAL & 5,448 & $£ 313,351,463$ \\
\hline
\end{tabular}

Council Tax revenue before reliefs was $£ 114$ million spread over 70,600 dwellings, an average of $£ 1,600$ per dwelling. To calculate the revenue from business rates it is necessary to multiply the rateable value by the Uniform Business Rate (UBR). Small businesses - those with a rateable value below $£ 51,000$ are assigned a lower UBR. The total rateable value of these small businesses in the current rating list for Reading is $£ 55$ million. With a UBR of 0.466 , this produces a revenue before reliefs of $£ 26$ million. The total rateable value of properties with a rateable value of $£ 51,000$ or more is $£ 258$ million and, with a UBR of 0.479 , the gross revenue is $£ 124$ million. This makes a total Business Rates revenue before reliefs of $£ 150$ million, an average of $£ 27,000$ per business property.

Net of reliefs, revenue from Council Tax in $2017 / 18$ was $£ 92$ million, equating to $£ 1,300$ per dwelling, and from Business Rates it was $£ 124$ million $^{3}$ equating to $£ 23,000$ per property. The total recurrent land and property tax revenue for Reading in $2017 / 18$ is, therefore, $f 216$ million. To be revenue neutral, a land tax must yield this amount of revenue.

Table 6 categorises land use in Reading and summarises their areas. Figure 2 shows the 1,339 land use polygons on a map. In practice, some uses are likely to be exempt from a land tax so only those shaded will be included in the land tax valuation model.

these properties were temporary structures which, although in the Rating List, are not assessed for rating purposes.

${ }^{3}$ Source: GOV.UK, live tables on local government finance, last updated 27 June 2018). 
Table 6: Land use in Reading

\begin{tabular}{|l|l|r|}
\hline Code & Land use description & Area (m2) \\
\hline & Inland water & $1,015,156$ \\
\hline & Open or heath and moorland & $1,868,069$ \\
\hline a & Agriculture - mainly crops & $4,704,744$ \\
\hline b & Glass houses & 5,189 \\
\hline c & Farms & 19,138 \\
\hline d & Deciduous woodland & 662,151 \\
\hline e & Coniferous and undifferentiated woodland & 208,874 \\
\hline & Principal transport road & $5,382,868$ \\
\hline & Principal transport rail & 342,836 \\
\hline & Recreational land & $3,322,058$ \\
\hline f & Large complex buildings various use (travel/recreation/retail) & 346,601 \\
\hline g & Low density residential with amenities (suburbs and small & $15,421,783$ \\
\hline villages/hamlets) & $4,029,255$ \\
\hline i & Medium density residential with high streets and amenities & 570,369 \\
\hline j & Urban centres - mainly commercial/retail with residential pockets & 188,501 \\
\hline k & Industrial areas & $1,650,663$ \\
\hline I & Business parks & 187,627 \\
\hline m & Retail parks & 245,176 \\
\hline n & Primarily large commercial/industrial sites & 213,022 \\
\hline
\end{tabular}

Source: Geolnformation, compiled from Ordnance Survey Open Data and aerial photos 


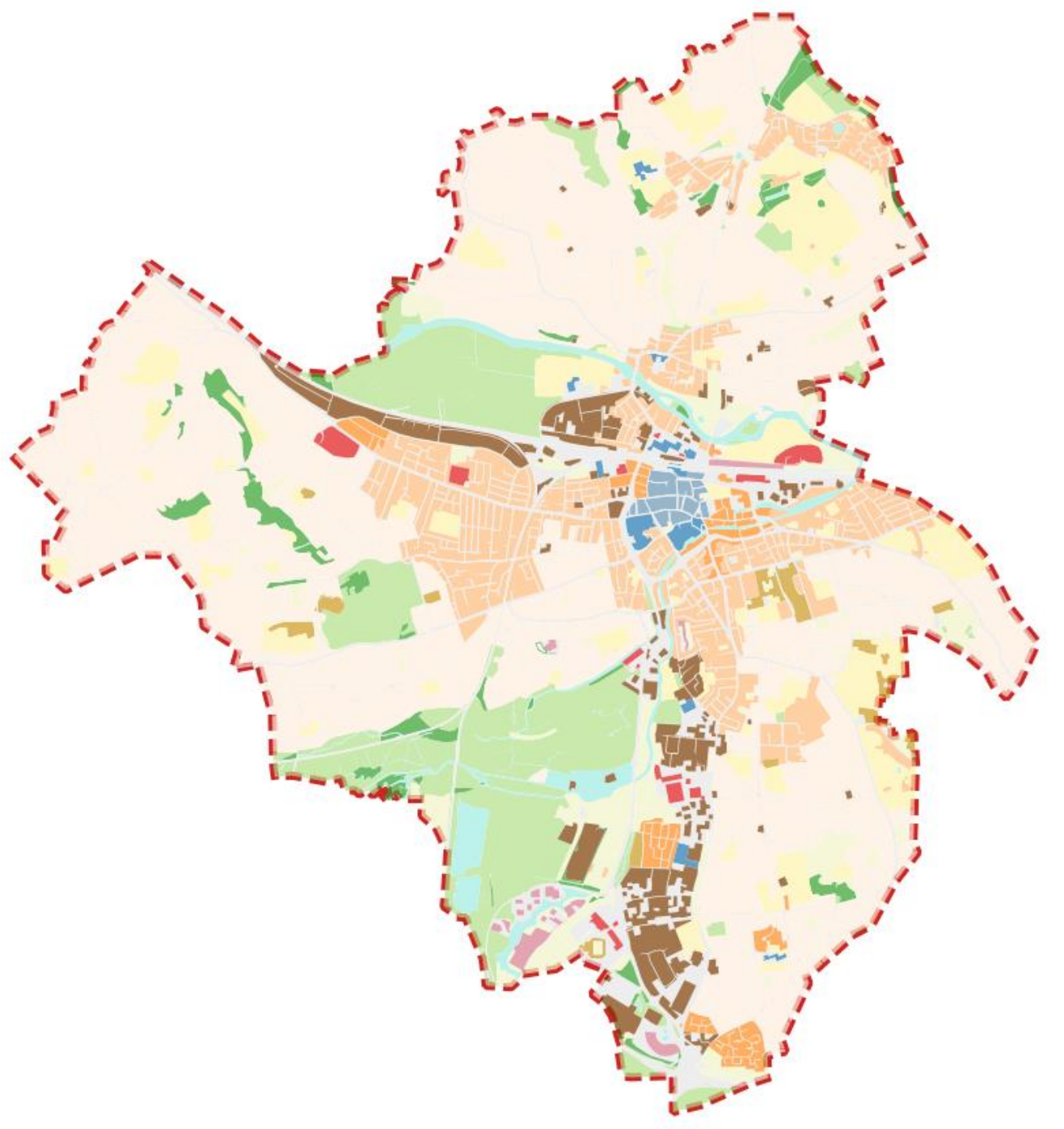

Agriculture - mainly crops

Business parks

Coniferous and undifferentiated woodland

Deciduous woodland

Farms

Glasshouses

High density residential with retail and commercial sites

Industrial areas

Inland Water

Large complex buildings various use (travel/recreation/ retail)

Low density residential with amenities (suburbs and small villages / hamlets)

Medium density residential with high streets and amenities

Mining and spoil areas

Open or heath and moor land

Primarily large commercial/industrial sites

Principle Transport Rail

Principle Transport Road

Recreational land

Retail parks

Urban centres - mainly commercial/retail with residential pockets

Figure 2: Land use in Reading

Source: Geolnformation, compiled from Ordnance Survey Open Data and aerial photos 
These land use areas were used to calculate the land tax revenue for Reading using a residual valuation model in which estimated build costs are deducted from property values to arrive at land values. Separate valuation models were constructed for the non-domestic and domestic land uses listed in table 7. The residual method is therefore applied to the land uses that exist in Reading at the moment. If the tax was to be based on optimum rather than existing use then different land uses and possibly higher densities would be assumed.

Table 7: Land uses

\begin{tabular}{|l|c|}
\hline \multicolumn{1}{|c|}{ Land Use } & Land use code from Table 4 \\
\hline Agriculture & $\mathrm{a}, \mathrm{b}, \mathrm{c}, \mathrm{d}, \mathrm{e}$ \\
\hline Retail and leisure & $\mathrm{f}, \mathrm{j} / 2, \mathrm{~m}$ \\
\hline Office & $\mathrm{j} / 2, \mathrm{I}, \mathrm{n} / 2$ \\
\hline Industrial and storage & $\mathrm{k}, \mathrm{n} / 2$ \\
\hline Detached houses & $\mathrm{g}$ \\
\hline Semi-detached houses & $\mathrm{g}$ \\
\hline Terraced houses & $\mathrm{h}$ \\
\hline Apartments & $\mathrm{i}$ \\
\hline
\end{tabular}

The residual valuations were based on the land use specific assumptions set out in table 8 . The values of residential units were based on transaction prices obtained from the Office for National Statistics ${ }^{4}$. Rental values and investment yields for retail, office and industrial space were obtained from CoStar ${ }^{5}$. Agricultural land values were based on estimates published by the UK Government (MHCLG, 2018a).

Build cost estimates ${ }^{6}$ were obtained from the Building Cost Information Service ${ }^{7}$ of the Royal Institution of Chartered Surveyors. Planning costs are assumed to cover any planning obligations and community infrastructure levy that may be required. Building sizes were obtained from CABE (2010) and DLCG (2016). Development density or floorspace-to-land ratio is a difficult metric to find evidence for. In 2017 the Government's Land Use Change Statistics recorded a density of 32

\footnotetext{
${ }^{4}$ House Price Statistics for Small Areas (HPSSAs). HPSSA Dataset 12. Mean price paid for administrative geographies.

${ }^{5}$ www.costar.co.uk

${ }^{6}$ Mean average costs (including preliminary costs) per square metre of gross internal area of new space in Reading for the fourth quarter of 2017.

7 http://www.bcis.co.uk/
} 
addresses per hectare on for new developments, but higher at 40 addresses on previously developed or brownfield land and lower at 26 addresses on non-previously developed or greenfield land (MHCLG, 2018b). Assuming an average dwelling size of 90 square metres that equates to 4,000 square metres of residential floorspace per hectare, i.e. $40 \%$ density. Indicative density for Reading town centre is 100 dwellings per hectare (dph) or higher, for urban areas it is 60-120 dph and for suburban it is $30-60 \mathrm{dph}^{8}$. The densities for town and city centres - where apartments are assumed to be the predominant form for residential development - is in line with the assumption made in DCLG (2015) . Densities for commercial land uses are very difficult to find evidence for. Town centres may be close to $100 \%$ site coverage, more for office space.

Table 8: Residual valuation assumptions

\begin{tabular}{|c|c|c|c|c|c|c|c|}
\hline & $\begin{array}{l}\text { Apart- } \\
\text { ments }\end{array}$ & $\begin{array}{c}\text { Terraced } \\
\text { houses }\end{array}$ & $\begin{array}{c}\text { Semi- } \\
\text { detached } \\
\text { houses }\end{array}$ & $\begin{array}{l}\text { Detached } \\
\text { houses }\end{array}$ & $\begin{array}{c}\text { Office } \\
\text { (centre) }\end{array}$ & $\begin{array}{l}\text { Office } \\
\text { (out of } \\
\text { town) }\end{array}$ & $\begin{array}{c}\text { Industrial \& } \\
\text { storage }\end{array}$ \\
\hline Values $(\mathrm{f} / \mathrm{m} 2)$ & $£ 4,035$ & $£ 4,456$ & $£ 4,029$ & $£ 4,796$ & $£ 4,508$ & $£ 3,607$ & $f 1,818$ \\
\hline $\begin{array}{l}\text { Build cost } \\
(\mathrm{f} / \mathrm{m} 2)\end{array}$ & $£ 1,599$ & $f 1,332$ & $£ 1,309$ & $£ 1,534$ & $£ 1,905$ & $f 1,500$ & $£ 1,119$ \\
\hline $\begin{array}{l}\text { External works } \\
\text { (\% build cost) }\end{array}$ & $15 \%$ & $15 \%$ & $15 \%$ & $15 \%$ & $10 \%$ & $10 \%$ & $10 \%$ \\
\hline $\begin{array}{l}\text { Planning costs } \\
\text { (\% value) }\end{array}$ & $15 \%$ & $15 \%$ & $15 \%$ & $15 \%$ & $5 \%$ & $5 \%$ & $0 \%$ \\
\hline $\begin{array}{l}\text { Net:gross floor } \\
\text { area ratio }\end{array}$ & - & - & - & - & $80 \%$ & $80 \%$ & $100 \%$ \\
\hline Building size & $\begin{array}{c}61 \mathrm{~m} 2 \\
\text { (2-bed } \\
\text { flat) }\end{array}$ & $\begin{array}{l}71 \mathrm{~m} 2 \\
\text { (2-bed } \\
\text { house) }\end{array}$ & $\begin{array}{l}96 \mathrm{~m} 2 \\
\text { (3-bed } \\
\text { house) }\end{array}$ & $\begin{array}{l}121 \mathrm{~m} 2 \\
\text { (4-bed } \\
\text { house) }\end{array}$ & - & - & - \\
\hline $\begin{array}{l}\text { Floorspace:plot } \\
\text { size ratio }\end{array}$ & $200 \%$ & $50 \%$ & $40 \%$ & $30 \%$ & $300 \%$ & $200 \%$ & $100 \%$ \\
\hline Building period & 2 years & 2 years & 2 years & 2 years & $\begin{array}{c}1.5 \\
\text { years }\end{array}$ & $\begin{array}{c}1.5 \\
\text { years }\end{array}$ & 1 year \\
\hline
\end{tabular}

In addition to the land use specific assumptions itemised in table 8 , the following generic assumptions were also made:

- Finance at $6 \%$ per annum on half build costs and fees over the building period

\footnotetext{
${ }^{8}$ Draft Reading Borough Plan, May 2017, p66, Reading Borough Council

${ }^{9}$ In that report it was assumed that a hypothetical scheme for a one-hectare $(10,000 \mathrm{~m} 2)$ site would be a multistorey development of 269 units comprising one, two, three and four bed flats with a gross building area of $23,202 \mathrm{~m} 2$ and a net sales area of $19,722 \mathrm{~m} 2$.
}

${ }^{10}$ This density assumption has a significant impact on the residual land value. 
- Land acquisition costs (Stamp Duty Land Tax plus legal and agent's fees) at $6.5 \%$ of land price

- Developer's return at $20 \%$ of development value

- Fees for construction professionals at $12.5 \%$ of build costs

- Marketing and sale costs at $2 \%$ development value

The residual valuation model, and its application to each of the land uses, is shown in the appendix. The gross development values of the commercial and industrial land are very sensitive to the choice of yields

\section{RESULTS}

Table 9 shows the resultant land values from the residual model for each land use together with the tax revenue. A tax rate of $3.00 \%$ is required to approximately match the revenue from the current property taxes.

Table 9: Land tax results from the residual model

\begin{tabular}{|l|r|r|r|r|r|}
\hline \multicolumn{1}{|c|}{ Land use } & \multicolumn{1}{|c|}{ Area (m2) } & \multicolumn{1}{|c|}{$\begin{array}{c}\text { Land value } \\
\mathbf{( f / h a )}\end{array}$} & Land value (f) & $\begin{array}{r}\text { Tax revenue } \\
\text { at a rate of } \\
\mathbf{3 . 0 0 \%}\end{array}$ & $\begin{array}{c}\text { Tax } \\
(\mathbf{f} / \mathbf{m} 2)\end{array}$ \\
\hline Commercial (city centre) & 188,501 & $22,315,579$ & $420,651,465$ & $12,619,544$ & 66.95 \\
\hline Commercial (out of town) & 885,915 & $11,902,038$ & $1,054,419,865$ & $31,632,596$ & 35.71 \\
\hline Residential (low density) & $15,421,783$ & $2,441,527$ & $3,765,269,469$ & $112,958,084$ & 7.32 \\
\hline $\begin{array}{l}\text { Residential (medium } \\
\text { density) }\end{array}$ & $4,029,255$ & $3,349,019$ & $1,349,405,153$ & $40,482,155$ & 10.05 \\
\hline Residential (high density) & 570,369 & $9,269,725$ & $528,716,808$ & $15,861,504$ & 27.81 \\
\hline Industrial & $1,757,174$ & 125,137 & $21,988,727$ & 659,662 & 0.38 \\
\hline Agriculture & $5,600,067$ & 22,500 & $12,600,150$ & 378,004 & 0.07 \\
\hline TOTAL & $28,453,065$ & & $7,153,051,636$ & $214,591,549$ & \\
\hline
\end{tabular}

The proportion of total tax revenue that is generated by agricultural land is very small, although it should be noted that the amount of agricultural land in the Reading borough is very low. By far the largest proportion of tax revenue is generated from low density residential and this is likely to be the 
case for many parts of England, particularly in the south east, because of the combination of high land values and low density (land extensive) development.

So the taxable land in Reading is valued at a total of $£ 7.2$ billion and this generates a tax revenue of approximately $f 215$ million assuming a tax rate of $3 \%$, close to the $f 216$ million generated from current Council Tax and Business Rates. However, the rate is not the crucial issue here. What is particularly noteworthy is the shift of tax liability from businesses to residents. In 2017 businesses generated $57 \%$ of revenue from recurrent property taxes in Reading (the same proportion as for England as a whole) and residents generated the remaining 43\%. The land tax shifts the burden substantially from business ( $21 \%$ of revenue) to residents ( $79 \%$ of revenue).

This shift is, in part, an outcome of different tax rates that are currently applied to domestic and non-domestic properties. As a proportion of capital value, the tax rate on non-domestic properties is higher than for domestic properties. In December 2017 the average house price in Reading was $£ 311,823$ and the average Council Tax Bill was $£ 1,365$ or $0.4 \%$ of capital value. For non-domestic property the uniform business rate was $47.9 \%$ in 2017/18 and, if we assume a capitalisation rate of $6 \%$, this is an effective tax rate on capital value of $2.9 \%$. If, under a new land tax, a common tax rate is applied, then there will be a substantial redistribution of the tax burden from non-domestic to domestic properties. The expectation is that the redistribution would be less marked for dwellings in high Council Tax bands, but this depends on the relative sizes of land parcels across the Council Tax value bands; low value dwellings with large plots may see a large redistribution.

In order to look further at the revenue implications of switching from an occupier tax to ownership tax, it is useful to examine the size and composition of the tax base. To begin, it is possible to tally the number of taxpayers in Reading under the current property tax system and compare that with the number of ownership parcels. Freehold parcel extents are published by the Land Registry and these are illustrated in red outline for the centre of Reading in figure 3, overlaying the land use map (from figure 2). In total there are 55,014 freehold parcels covering the whole of the Reading borough, although there are a few gaps where land has not been registered yet. This contrasts with the 70,600 dwellings that are liable for Council tax and 5,448 properties liable for Business rates. This is a total of 76,048 taxable entities. Therefore, a switch to a land tax on owners would see a reduction in the size of the tax base of 21,034 tax payers (28\%). 


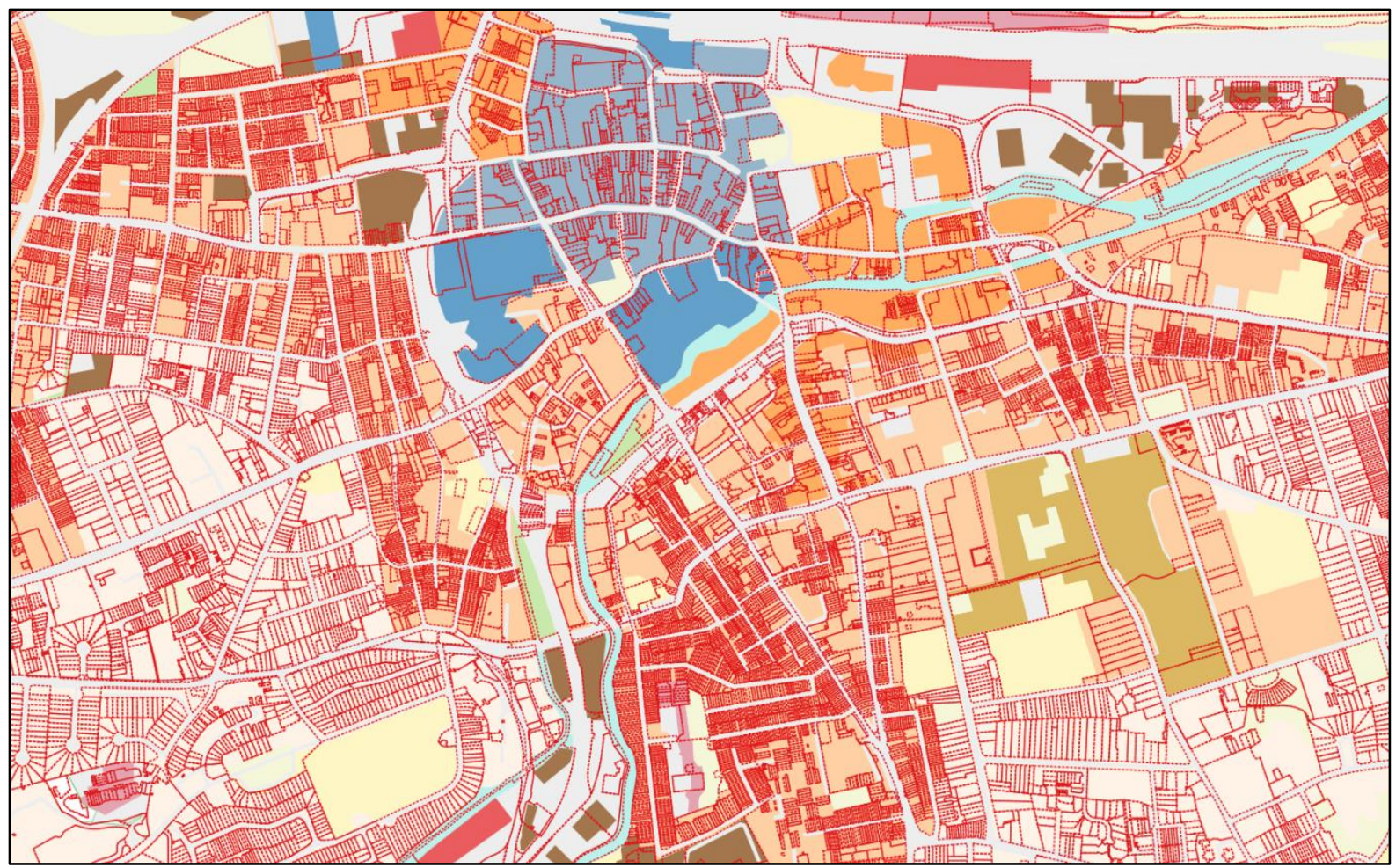

Figure 3: Freehold parcel extents (red outlines) for central Reading, overlaying the land use map

Source: The HM Land Registry INSPIRE Index Polygons dataset is subject to Crown copyright and is reproduced with the permission of HM Land Registry

(C) Crown copyright and database rights 2018 Ordnance Survey 100026316)

The next step is to take a more detailed look at land uses of the freehold parcels, both in terms of number of parcels and land area. This requires a spatial overlay using a GIS to allocate each freehold parcel to a land use. For most parcels this is straightforward as they can be entirely allocated to the relevant land use. A small number, though, straddle more than one land use. In these cases, the freehold parcel was duplicated and allocated to each land use that it straddled. This explains why the total number of freeholds in table 10 is slightly greater than the original 55,014. 
Table 10: Taxation of freeholds in Reading

\begin{tabular}{|l|r|r|r|r|r|}
\hline \multicolumn{1}{|c|}{ Land use } & Area $\mathbf{( m 2 )}$ & $\begin{array}{r}\text { Number of } \\
\text { freeholds }\end{array}$ & $\begin{array}{r}\text { Area per freehold } \\
\mathbf{( m 2 )}\end{array}$ & $\begin{array}{c}\text { Tax } \\
(\mathbf{f} / \mathbf{h a})\end{array}$ & $\begin{array}{r}\text { Tax per } \\
\text { freehold }\end{array}$ \\
\hline Commercial (city centre) & 188,501 & 364 & 518 & 66.95 & 34,669 \\
\hline Commercial (out of town) & 885,915 & 332 & 2,668 & 35.71 & 95,279 \\
\hline Residential (low density) & $15,421,783$ & 36,583 & 422 & 7.32 & 3,088 \\
\hline Residential (medium density) & $4,029,255$ & 16,056 & 251 & 10.05 & 2,521 \\
\hline Residential (high density) & 570,369 & 1,235 & 462 & 27.81 & 12,843 \\
\hline Industrial & $1,757,174$ & 1,193 & 1,473 & 0.38 & 553 \\
\hline Agriculture & $5,600,067$ & 1,181 & 4,742 & 0.07 & 320 \\
\hline TOTAL & $28,453,065$ & 56,944 & & & \\
\hline
\end{tabular}

Looking at the switch from the current property taxes to a land tax, compared to 5,448 business rates properties, there are 1,877 freeholds classified as commercial and industrial. Compared to 70,600 Council Tax dwellings, there are 53,874 freeholds classified as residential land use. The 1,181 freeholds classified as agricultural would be new to the tax base. The average area per freehold is also shown in the table, and this allows calculation of the average tax liability per entity. The tax per agricultural land owner is very low due to their small size (a little under half of one hectare on average). This reflects the composition of agricultural land ownership in the Reading borough which contains mainly small land holdings, which tend to be more valuable per unit area than large farms.

For city centre and out of town commercial land, the tax liability per freehold is much higher ( $£ 35,000$ and $£ 95,000$ respectively, compared to $£ 23,000$ per property under Business Rates in 2017). Many of these freeholds, and particularly those located out of town, will comprise multiple occupiers in office buildings, shopping centres, retail and business parks. The major shift is for residential dwellings; the average Council Tax bill was $£ 1,300$ per dwelling in 2017 but under the modelled land tax this would increase to $£ 3,000$ for low density, $£ 2,500$ for medium density and $£ 13,000$ for high density residential freeholds. The high-density amount is much higher because each freeholder is likely to have multiple residential occupiers and the tax liability would probably be shared among those occupants. 


\section{CONCLUSIONS}

The two research questions were: how might the valuation of land be undertaken in England where most transactional evidence relates to land and property and what are the revenue implications of switching from a tax where the liability falls on the land owner rather than the property occupier in first instance?

The lack of transactional evidence for land sales is a significant concern for land tax administration. What little evidence there is often requires adjustment to account for differences between parcels, not least as a result of locational differences that can have a substantial influence on value. Land prices may also reflect alternative use value and development (hope) value and, if a land tax is based on such prices, owners may have difficulty in paying tax if they are using the land for a lower value use. For example, the owner of an organic farm may be required to pay a tax based on land value that assumes the farm is used for intensive farming. Would government wish to penalise land owners who choose not to maximise economic value? Instead, a residual valuation model values land in its existing use and resorts to more fundamental evidence of build costs and property values to derive land value.

Switching from a property tax to a land tax is likely to create winners and losers, yet the scale of the shift from businesses to residents is considerable; from entities that don't vote to those that do, and this perhaps explains why it has never been done. Of course, the use of different tax rates can alleviate the shift and land owners would probably attempt to pass on the tax burden to occupiers in the form of rent or service charge, but this would only be possible where the market allows. Turning finally to agricultural land, expansion of the tax base to include this land use has a marginal impact in Reading but is likely to be more contributory where such land is more dominant in relation to urban land uses.

It is important to recognise that detailed and up to date land ownership records are essential, as is the existence of comprehensive land use planning and development control system. After all, land use allocation is a key value influence, and land values are very sensitive to planning assumptions. Further research will examine a rural case study area to investigate in more detail the implications of including agricultural land in the tax base. Areas of investigation are likely to include the requirements for a complete and up to date register of land ownership, establishing highest and best use and separating land value from land and property value. 


\section{REFERENCES}

CABE (2010) Dwelling Size Survey, report by Scott Wilson for CABE, Commission for Architecture and the Built Environment, April 2010.

Connellan, O. (2004) Land value taxation in Britain: experience and opportunities. Lincoln Institute of Land Policy. Cambridge, Massachusetts.

Corlett, A., Dixon, A., Humphrey, D. and von Thun, M. (2018) Replacing Business Rates: taxing land, not investment.

Corlett, A. and Gardiner, L. (2018) Home affairs: options for reforming property taxation. Intergenerational Commission Report. Resolution Foundation. March 2018.

DCLG Land Use Statistics (Generalised Land Use Database) 2005 for Reading. Department for Communities and Local Government.

DCLG (2016) English Housing Survey: Housing Stock Report, 2014-15. Department for Communities and Local Government. July 2016

Dunne, T. (2005) Land value taxation: persuasive theory but practically difficult. Dublin Institute of Technology. Property Valuer, IAVI, Dublin, Ireland. Spring 2005.

Dye, R. and England, R. (2010) Assessing the theory and practice of land value taxation. Policy Focus Report. Lincoln Institute of Land Policy. Cambridge, Massachusetts.

Gibb, K. and Christie, L. (2015) International literature review for the Commission on Local Tax Reform. In The Commission on Local Tax Reform: Volume 3 - Compendium of Evidence. pp. 126164.

George, H. (2005) Progress and Poverty. Cosimo Classics. New York. (Originally published in 1879 by E. P. Dutton and Company.) 
Hills, J. and Sutherland, H. (1991) The Proposed Council Tax, Fiscal Studies, Vol 12, No 4, 1-21.

IPPR (2005) Time for land value tax? D. Maxwell and A. Vigor (eds.) Institute for Public Policy Research and the Department of Politics and International Relations at the University of Oxford.

Land Institute (1973) Site Value Rating: Report on a Research Carried Out in the Town of Whitstable, January 1974

Leishman, C., Bramley, G., Stephens, M., Watkins, C. and Young, G. (2004) After the Council Tax: impacts of property tax reform on people, places and house prices. Joseph Rowntree Foundation.

Lichfield, N. and Connellan, O. (1997) Land value taxation in Britain for the benefit of the community: history, achievements and prospects. Lincoln Institute of Land Policy Working Paper. WP98NL1. Lincoln Institute of Land Policy.

Lyons, R. (2011) Residential site value tax in Ireland: an analysis of valuation, implementation and fiscal outcomes. Smart Taxes Network.

Lyons, R. and Wightman, A. (2013) A land value tax for Northern Ireland. Research Report: seven. Centre for Economic Empowerment.

MHCLG (2018a) Land value estimates for policy appraisal: May 2017 values. Ministry of Housing, Communities and Local Government. May 2018.

MHCLG (2018b) Land Use Change Statistics in England: 2016-17, Ministry of Housing, Communities and Local Government. Planning: Statistical Release. 31 May 2018.

McGill, G. and Plimmer, F. (2004) An Examination in to the Effects of Land Value Taxation in the UK: An Update of the Whitstable Case Studies, Lincoln Institute of Land Policy Working Paper, WP04GM1.

Mirlees, J., Adam, S., Besley, T., Blundell, R., Bond, S., Chote, R., Gammie, M., Johnson, P., Myles, G. and Poterba, J. (2011) Tax by Design: The Final Report of the Mirlees Review. Institute for Fiscal Studies. 
Norregaard, J. (2013) Taxing immoveable property: revenue potential and implementation challenges. International Monetary Fund. IMF Working Paper. WP/13/129.

Rating and Valuation Association (1964) Rating of Site Values: Report on a Pilot Survey at Whitstable.

de Soto, H. (2000) The mystery of capital: why capitalism triumphs in the west and fails everywhere else. Black Swan, London.

UN (2011) Land and property tax: a policy guide. United Nations Habitat and the Global Land Tool Network.

Wightman, A. (2013a) A land value tax in England: fair, efficient, sustainable.

Wightman, A. (2013b) A land value tax for Scotland: fair, efficient, sustainable. 


\section{DEVELOPMENT VALUE:}

Mean price paid for each dwelling $(f)$

Average size (sqm GIA)

Mean price paid per square metre

( $£$ /sqm GIA)

Sale costs (\% Development Value)

Development value ( $\mathrm{f} / \mathrm{sqm}$ )

\section{DEVELOPMENT COSTS:}

Build cost ( $f /$ sqm GIA)

Professional fees (\% build costs)

Site, infrastructure and abnormal

costs (\% build costs)

Planning costs (\% development value)

Construction cost ( $\mathrm{f} / \mathrm{sqm}$ )

Loan (\% p.a.)

Development period (yrs)

Finance cost ( $f /$ sqm)

Developer's return (\% development

value)

Developer's return ( $f / s q m)$

Development cost ( $\mathrm{f} / \mathrm{sqm})$

Land purchase costs (\% RLV)

Residual Land Value ( $\mathbf{f} / \mathrm{sqm}$ )

Density

$\operatorname{RLV}(\mathrm{f} / \mathrm{ha})$
Semi-

\begin{tabular}{|c|c|c|c|c|c|c|c|}
\hline Apartments & Terraced & detached & Detached & DEVELOPMENT VALUE: & (centre) & (out) & Industria \\
\hline 246,117 & 316,373 & 386,818 & 580,276 & Rent $(f / m 2)$ & 275 & 275 & 100 \\
\hline 61 & 71 & 96 & 121 & Yield (\%) & $6.10 \%$ & $6.10 \%$ & $5.50 \%$ \\
\hline 4035 & 4456 & 4029 & 4796 & Gross Development Value $(\mathrm{f} / \mathrm{m} 2)$ & 4508 & 4508 & 1818 \\
\hline $2.00 \%$ & $2.00 \%$ & $2.00 \%$ & $2.00 \%$ & Sale costs (\% Development Value) & $2.00 \%$ & $2.00 \%$ & $2.00 \%$ \\
\hline \multirow[t]{2}{*}{3956} & 4369 & 3950 & 4702 & Development value $(\mathrm{f} / \mathrm{m} 2)$ & 4420 & 4420 & 1783 \\
\hline & & & & DEVELOPMENT COSTS: & & & \\
\hline 1599 & 1332 & 1309 & 1534 & Build cost $(f / m 2$ GIA) & 1905 & 1500 & 1119 \\
\hline $12.5 \%$ & $12.5 \%$ & $12.5 \%$ & $12.5 \%$ & $\begin{array}{l}\text { Professional fees (\% build costs) } \\
\text { Site, infrastructure and abnormal }\end{array}$ & $12.5 \%$ & $12.5 \%$ & $12.5 \%$ \\
\hline $15 \%$ & $15 \%$ & $15 \%$ & $15 \%$ & costs (\% build costs) & $10 \%$ & $10 \%$ & $10 \%$ \\
\hline $15 \%$ & $15 \%$ & $15 \%$ & $15 \%$ & Planning costs (\% development value) & $5 \%$ & $5 \%$ & $0 \%$ \\
\hline 2632 & 2354 & 2262 & 2661 & Construction cost (f/m2) & 2555 & 2058 & 1371 \\
\hline $6.00 \%$ & $6.00 \%$ & $6.00 \%$ & $6.00 \%$ & Loan (\% p.a.) & $6.00 \%$ & $6.00 \%$ & $6.00 \%$ \\
\hline 2.00 & 2.00 & 2.00 & 2.00 & Development period (yrs) & 1.50 & 1.50 & 1.00 \\
\hline 163 & 145 & 140 & 164 & $\begin{array}{l}\text { Finance cost }(\mathrm{f} / \mathrm{m} 2) \\
\text { Developer's return (\% development }\end{array}$ & 117 & 94 & 41 \\
\hline $20 \%$ & $20 \%$ & $20 \%$ & $20 \%$ & value) & $20 \%$ & $20 \%$ & $20 \%$ \\
\hline 791 & 874 & 790 & 940 & Developer's return $(£ / m 2)$ & 884 & 884 & 357 \\
\hline 3586 & 3373 & 3191 & 3766 & Development cost $(\mathrm{f} / \mathrm{m} 2)$ & 3555 & 3036 & 1768 \\
\hline $6.50 \%$ & $6.50 \%$ & $6.50 \%$ & $6.50 \%$ & Land purchase costs (\% RLV) & $6.50 \%$ & $6.50 \%$ & $6.50 \%$ \\
\hline 309 & 832 & 634 & 782 & Residual Land Value $(\mathrm{f} / \mathrm{m} 2)$ & 744 & 1190 & 13 \\
\hline $300 \%$ & $50 \%$ & $40 \%$ & $30 \%$ & Density & $300 \%$ & $100 \%$ & $100 \%$ \\
\hline $9,269,725$ & $4,160,960$ & $2,537,078$ & $2,345,976$ & $\begin{array}{l}\text { RLV ( } f / \text { ha based on specified density) } \\
\text { (Eng) }\end{array}$ & $22,315,579$ & $11,902,038$ & 125,137 \\
\hline
\end{tabular}


